\title{
Raw image
}

for Figure $3 a$

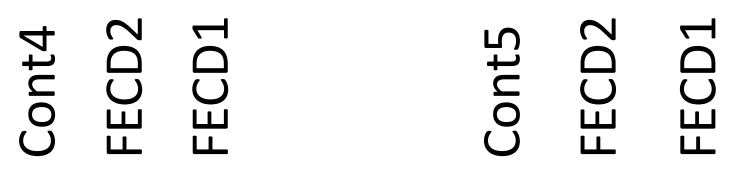

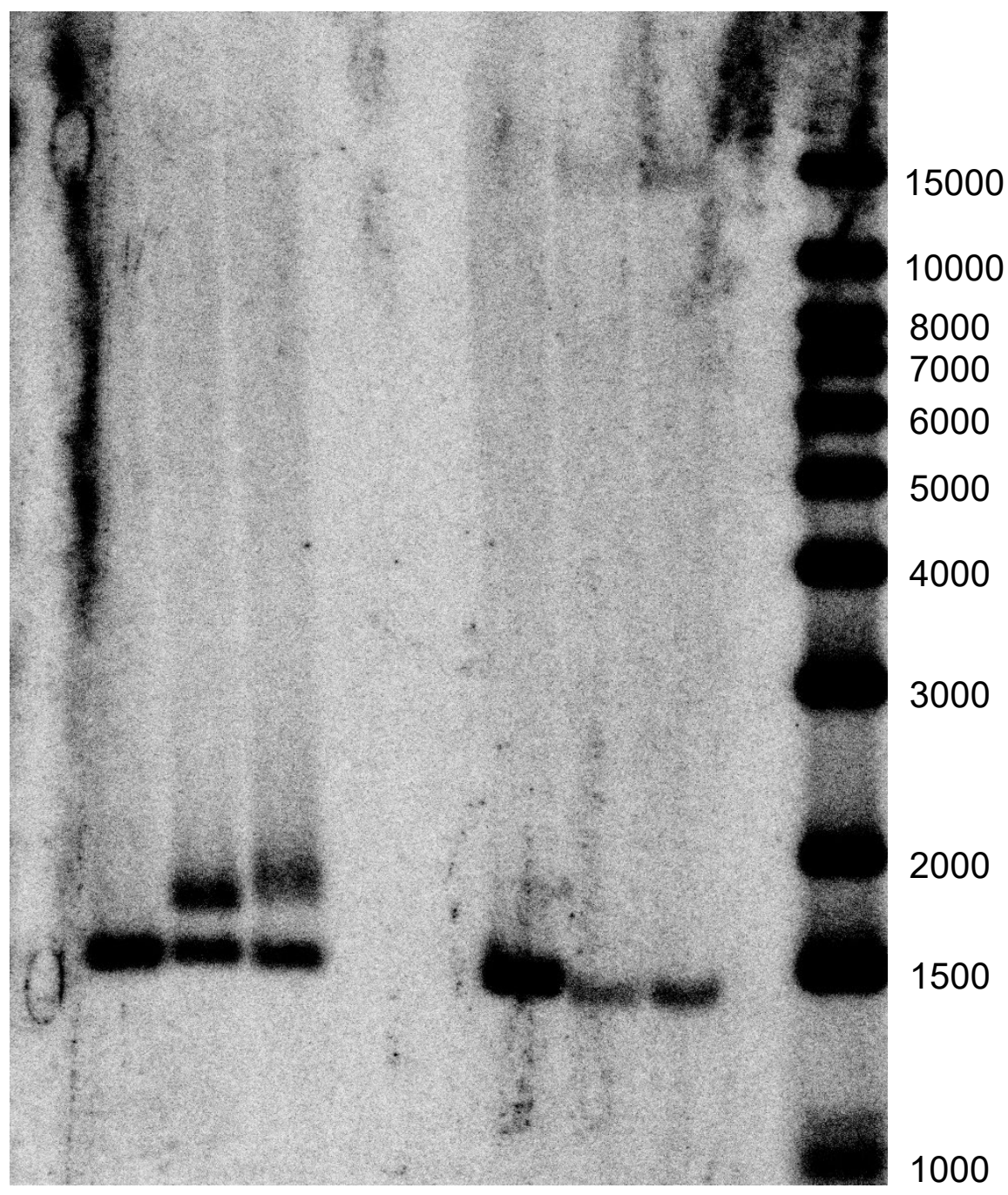


